\title{
Determinant Factors of Female Workers Job Satisfaction
}

\author{
Yohana F. Cahya Palupi Meilani ${ }^{1}$ \\ \{yohana.meilani@uph.edu $\left.{ }^{1}\right\}$ \\ ${ }^{1}$ Department of Management, Pelita Harapan University, M.H Thamrin Street- Karawaci, Tangerang, \\ Indonesia
}

\begin{abstract}
The purpose of this study is to determine factors of female workers job satisfaction. This study will see the positive effect of supervisory, financial compensation and internal motivation on job satisfaction of female workers. The importance of this study, based on phenomenon of high absenteeism of female workers and the impact is production target had not been reached. Quantitative approach applied, with descriptive method. Data collection technique using questionnaire with five Likert-scale to 100 respondents with purposive random sampling. Then the data was analysed using Smart PLS program. The results indicate that supervisory, financial compensation and internal motivation have positive effect on female workers job satisfaction. Contribution of this research is giving input to the managerial and decision maker in human resource field how in maintaining job satisfaction for female workers.
\end{abstract}

Keywords: Job Satisfaction, Female Workers, Supervisory, Financial Compensation, Internal Motivation

\section{Introduction}

The data from Indonesia's Bureau of Statistics (BPS, 2017) shown rate of female labor participation increased. For example, in February 2016 is 55.04\%. So female employees also need to be empowered and considered as an important asset to pay attention to their job satisfaction. Sutrisno (2011) said, one thing that needs to be considered in managing human resource in the company is job satisfaction. Because job dissatisfaction can affect several things, such as productivity, absenteeism, health. Survey by jobplanet.com (2016) using 46.650 respondents from banking sector found that female workers are more satisfied than male workers.

Based on exploration study to 100 male workers and female workers at X company. They mention three dominant factors in job satisfaction including financial compensation; supervisory and internal motivation. $\mathrm{X}$ is manufacturing company produce children's toys. Then Production target is very important. X has 474 female workers. Unfortunately during 2016-2017 there was a high level of absenteeism of female workers. The impact is production target cannot be achieved. To decrease the risk of productivity, $\mathrm{X}$ should be maintaining workers job satisfaction including female workers.

There are various previous studies related to job satisfaction. As have been done by Sari, 2009; Muttaqien, 2014; Mawei, Nelwan and Uhing, 2014; Mardiono and Supriyatin, 2014; Ratnasari and Dewi, 2014; Rozzaid, Herlambang and Devi, 2015. However, previous research has not been done for female workers. Then this study aims to see the influence of supervisory, financial compensation and internal motivation to job satisfaction of female workers. Based on the background above, the problem formulation is as follows:

1. Does supervisory have a positive effect on job satisfaction of female workers? 
2. Does financial compensation have a positive effect on job satisfaction of female workers?

3. Does the motivation have a positive effect on job satisfaction of female workers?

Contribution of this research to give input to the managerial and decision maker in human resource field how maintaining job satisfaction for female workers in manufacturing industry.

\section{Literature Reviews}

\subsection{Human Resource Management}

Schermerhorn (2013) define that, human resource management is a process of engaging, developing and sustaining manpower. Dessler (2014) said that human resource management is a process of obtaining, training, assessing and compensating employees directly related to employment, health, safety and justice relationships for employees. Then Mathis and Jackson (2011), focuses three of the human resource management role: Administrative roles; Operations employee advocates; and Strategic.

\subsection{Supervisory}

French et al (2015), stated that supervisory is kind of leadership act is an interpersonal case to influence a person or group to do what the leader wants. Sharma and Jain (2013) stated that supervisory is running when a supervisor interacts with subordinate and encourage achieving the goal by cohesiveness of teamwork. French et al $(2015,289)$ also explains the duties of a supervisor among them is to inspire, create opportunities and train, and motivate employees to grow. Schermerhorn (2013) also affirms that respect for supervisor is derived from the integrity that the supervisor possesses. Supported statement by Sutrisno (2011) and French et al (2015) explains that in an organization, the supervisory factor plays an important role.

\subsection{Compensation}

Dessler (2014), states that compensation is any form of salary or award given to employees by employees of their work. Compensation can also be used to influence employee behavior to improve company performance. Compensation is divided into two components (direct financial payments and indirect financial payments). Included in direct financial payments are wages, salaries, incentives, commissions and bonuses. While those included in indirect financial payments are insurance and leave allowance. Sutrisno (2011) also argues direct compensation is the compensation given directly related to the work of the employees concerned. As for indirect compensation, the provision of compensation is not associated with the work of the employees concerned. This indirect compensation is also called complementary compensation. For reasons, such as the cost of living is getting bigger or demanding a lot of income sources for employee, such as health facilities, allowances, transportation.

\subsection{Motivation}

Motivation describes as the work impulses of the individual in the degree, direction and persistence he performs at work (Schemerhorn, 2013). Every organization would want to achieve its goals. To achieve that goal, the role of the people involved in it is very important. Meanwhile, according to Sutrisno (2011) internal motivation is a factor that triggers a person 
to perform a certain activity. On this basis, it is often called motivation as a factor that encourages one's behavior.

\subsection{Job Satisfaction}

Aziri (2011) says that job satisfaction is one of the complex areas that managers face today. The negative consequences of job dissatisfaction, such as lack of loyalty to the company, increasing the number of absences and accidents, and others. According to Schermerhorn (2013), job satisfaction is a positive or negative level that explains a person's feelings toward a job. Meanwhile, Mathis and Jackson (2011) said that, job satisfaction is an emotional state resulting from. The factors of job satisfaction usually include employee relations, compensation, recognition of good performance, and communication with superiors. Dessler (2014) and Sutrisno (2011) also said that employees who are not satisfied with their work tend to want to leave their jobs.

\subsection{Relationship Between Variables}

\subsubsection{Relationship Supervisory and Job Satisfaction}

Supervisory has an important role in efforts to improve work performance, both at the individual, group, and organizational levels (Sutrisno, 2011). So it can be said that, supervisory has a positive effect on job satisfaction. This statement is also reinforced by the opinions of Ratnasari and Dewi, 2014; Firmansyah, 2008; Paripurna, 2013; Muttaqien, 2014; Mawei, Nelwan dan Uhing, 2014 who are argue that when a supervisor can lead well, then employees will have job satisfaction. Then a hypothesis is:

H1: Supervisory has positive effect on job satisfaction of female workers.

\subsubsection{Relationship Financial Compensation and Job Satisfaction}

There are various functions and objectives of giving compensation. Employees can fulfill their physical, social and egoistic needs. Then they feel satisfied of their job (Ardana, Mujiati and Utama, 2012). But Milkovich, Newman and Gerhart (2014) stated that if compensation is unfair can lead to unfavorable relationships between employees with their superiors, employees resist change in the company, job change, depression and loss of morale, and loss of job satisfaction. Schermerhorn (2013); Sari, 2009; Aziri, 2011; Muttaqien, 2014; Mawei, Nelwan dan Uhing, 2014; Rozzaid, Herlambang dan Devi, 2015; Potale dan Uhing, 2015 also argues that financial compensation is positively affected job satisfaction. Then a hypothesis is:

H2: Financial compensation has positive effect on job satisfaction of female workers.

\subsubsection{Relationship Internal Motivation and Job Satisfaction}

Motivation is also considered as a factor that encourages a person to perform a certain activity including for female workers. Therefore, internal motivation is often interpreted also as a driver of one's behavior (Sutrisno, 2011). Mardiono and Supriyatin (2014), said that internal motivation is the spirit that is reflected in the discipline of employees who can create job satisfaction. Mawei, and Uhing (2014) also argue that internal motivation has a positive influence on job satisfaction. With internal motivation, employees will strive to work as much as possible in order to achieve job. Then, according Kartika and Kaihatu, 2010; Ratnasari and Dewi, 2014; Mardiono and Supriyatin, 2014; Rozzaid, Herlambang and Devi, 2015 stated that, motivation has a positive effect on job satisfaction. Then a hypothesis is: 
H3: Internal motivation has a positive effect on job satisfaction of female workers.

\section{Research Methodology}

\subsection{Paradigm And Type Of Research}

The paradigm used in this research is the quantitative paradigm. The type of research is descriptive research, which is tests hypotheses by means of statistics (Moleong, 2016). The purpose of this study is to determine the relationship between supervisory, financial compensation and internal motivation to job satisfaction of female workers. This research uses survey and hypothesis testing which will yield research conclusion, so it can be classified into descriptive category.

\subsection{Conceptual And Operational Definition}

In this study, each variable measured using five indicators. Supervisory (KPN): Supervisor can communicate well; Supervisor provides motivation; Supervisor has ability to lead; Supervisor can take the right decision; Supervisor uses his position for the sake of the company. Then financial compensation (KP): Salary received meets my expectations; Salary received accordance to my job; Salary received has been in accordance with my responsibility; Salary increase system applied has accordance my work periods; Overtime pay has met my expectations. Internal motivation (M): I have a desire to get an award; I want to give optimal results; I have intentions in working; I feel proud of the company; I have responsibility for my work. Job satisfaction (KK): I feel satisfied with my boss; I feel satisfied with my company; I feel satisfied with my coworkers; I have a chance to improve my skills; I get comfortable with my working conditions.

\subsection{Sampling Techniques}

The object of this research is X company, as one of biggest toys manufacturing industry in Indonesia. X produced products such as two-wheeled bikes, 3-wheeled bikes, baby walkers, baby strollers. As manufacturing company, $\mathrm{X}$ has 870 workers including females and males. Females are 474 workers. Subjects in this research are female workers of production division. Samples used justified random sampling with criteria female worker of production division who has been appointed as permanent employees for at least 1 year. The number of samples to be used in this research is 100 samples, which fit to Smart PLS Program to analysis the data.

\section{Findings And Discussion}

\subsection{Preliminary Study}

Preliminary study uses 70 respondents. Indicators that are not met the criteria of loading factor $<0.7$ cannot use at actual study, such as: supervisory (supervisor communicate well; make the right decision). Compensation (the system of salary increase applied has been in accordance with my working period). Internal motivation (I have the desire to get the award). In the job satisfaction (I feel satisfied with my work; I have the opportunity to improve the skills). 


\subsection{Measurement Model, Validity And Reliability}

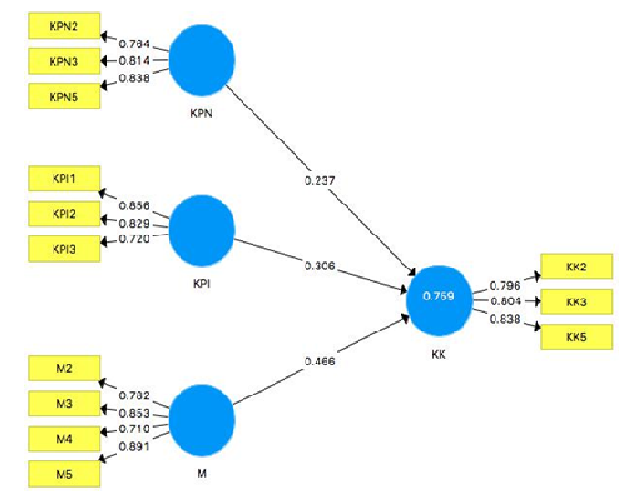

Fig.1. Model and Structural Model Measurements

Indicators are acceptable because they have value $>0.7$. For Internal motivation variable (M2, M3, M4 and M5). Supervisory variable (KPN2, KPN3, KPN5). Then Financial compensation variable (KP1, KP2, KP3). Job satisfaction variable, (KK2, KK3 and KK5). After testing the validity through factor loading, the next step is to test based on the average variance extracted (AVE) value.

Table 1. AVE Actual Study

\begin{tabular}{cc}
\hline Variables & AVE \\
\hline Supervisory & 0.65 \\
\hline Financial Compensation & 0.75 \\
\hline Internal Motivation & 0.66 \\
\hline Job satisfaction & 0.72 \\
\hline
\end{tabular}

Table 1 shown all variables have met the specified requirements. In testing actual validity also conducted discriminant testing. The discriminant validity test can be seen from the AVE quadratic root for any larger construct of the correlation between constructs in the model of Fornell-Lacker criterion.

Table 2. Discriminant Validity of Actual Research (Fornell-Lacker Criterion)

\begin{tabular}{ccccc}
\hline Variables & JS & FC & S & IM \\
\hline Job Satisfaction & $\mathbf{0 . 8 1 5}$ & & & \\
\hline $\begin{array}{c}\text { Financial } \\
\text { Compensation }\end{array}$ & 0.75 & $\mathbf{0 . 8 0 4}$ & & \\
\hline Supervisory & 0.640 & 0.660 & $\mathbf{0 . 8 0 6}$ & \\
\hline $\begin{array}{c}\text { Internal } \\
\text { Motivation }\end{array}$ & 0.801 & 0.755 & 0.605 & $\mathbf{0 . 8 1 2}$ \\
\hline
\end{tabular}

Table 2 shown that the first value in the row and column of each variables shown the highest value among the values below. Therefore, the AVE square root value is higher than the correlation value and can be declared valid. So the conclusion is that all variables in the actual study meet discriminant validity. The reliability test for actual research can be seen from the value of Cronbach's alpha that all variables have values $>0.7$. A data can be 
expressed as reliable data if the Cronbach's coefficient alpha value of the data is a minimum of 0.7 (Sekaran and Bougie, 2013). Here are the results of the actual research data processing.

Table 3. Reliability Test Actual Study

\begin{tabular}{cc}
\hline Variables & Cronbach Alpha \\
\hline Supervisory & 0.730 \\
\hline Financial Compensation & 0.725 \\
\hline Internal Motivation & 0.825 \\
\hline Job satisfaction & 0.735 \\
\hline
\end{tabular}

\subsection{Structural Model And Hypothesis Testing}

The first step in testing the structural model begins by testing multicollinearity by computing the Variance Inflation Factor (VIF). The variable undergoes multicolinearity if the resulting VIF value is greater than 10 or greater than five (Ghozali and Latan, 2015).

Table 4. VIF for Actual Study

\begin{tabular}{cc}
\hline Variables & VIF \\
\hline Supervisory & 1.557 \\
\hline Financial Compensation & 2.034 \\
\hline Internal Motivation & 2.125 \\
\hline Job satisfaction \\
\hline
\end{tabular}

Result of VIF calculation. Based on table 4 above, it can be seen that all variables have fulfilled the requirement, that is VIF value $<5$. Which means all variables does not have a high collinearity. Then, assessment of structural models can be evaluated using the Smart-PLS program by looking at the value of $\mathrm{R}$ square for each endogenous latent variable as the predictor force of the structural model (Ghozali and Latan, 2015). The result of R-Square indicates the number of variants of the construct described by the model. The calculation of RSquare is $0.861(86.1 \%)$, predicted model of endogenous variables belongs to the strong category. In other words, there is $13.9 \%$ other factors affecting endogenous variables not found in this research model. Other factors may also effect job satisfaction, such as promotion, working conditions, job security, employee relations and other factors. Next, model evaluation is done by looking at the significance value to know the influence between variables with bootstrapping method.

Table 5. Hypothesis Testing Result

\begin{tabular}{|c|c|c|c|}
\hline Hypothesis & $\begin{array}{l}\text { Original Sample } \\
(\mathrm{O})\end{array}$ & $\begin{array}{l}\text { Sample Mean } \\
\text { (M) }\end{array}$ & T-Statistic \\
\hline $\mathrm{H} 1: \mathrm{S} \rightarrow \mathrm{JS}$ & 0.247 & 0.248 & 4.246 \\
\hline $\begin{array}{c}\mathrm{H} 2: \\
\mathrm{FC} \rightarrow \mathrm{JS}\end{array}$ & 0.315 & 0.303 & 3.714 \\
\hline $\begin{array}{c}\text { H3: IM } \rightarrow \\
\text { JS }\end{array}$ & 0.468 & 0.472 & 6.879 \\
\hline
\end{tabular}

According to Ghozali and Latan (2015), whether or not a hypothesis is supported can be seen from t-value. T-value is tested with one tailed test or a one-way test with a significance level of $5 \%$. The requirement a hypothesis can be stated significant if the value of $t$-value exceeds 1.96. Based on Table 5 above, all hypotheses are supported. 


\subsection{Discussion And Managerial Implication}

From first hypothesis, "Supervisory has positive effects on job satisfaction of female workers." In accordance with Sutrisno, 2011; Schermerhorn, 2013 that supervisory has an important role improving work performance at individual, group, and organizational levels and give job satisfaction. Supervisor should provide enough motivation to his/her subordinates. In other words, supervisor has a significant effect on job satisfaction. According respondents female workers that supervisory at $\mathrm{X}$ has a significant effect on employee job satisfaction. Related and supported previous research from Firmansyah, 2008; Paripurna, 2013; Muttaqien, 2014; Mawei, Nelwan and Uhing, 2014.

Second hypothesis, "Financial compensation has a positive effect on job satisfaction of female workers." Milkovich, Newman and Gerhart (2014) argue that if compensation is perceived as unfair, it can lead to poor relationships between employees and employers, employees resist change in the company, want to change jobs, depression and loss of morale, and loss of satisfaction work. Ardana, Mujiati and Utama (2012) also argue by providing sufficient compensation to employees, employees can meet the needs of daily life, both physically, socially, and egoistic. In other words, compensation has a significant effect on job satisfaction. Indicates that the financial compensation at $\mathrm{X}$ has fulfilled the expectation of female workers. This result is accordance with previous research by Sari, 2009; Aziri, 2011; Muttaqien, 2014; Mawei, Nelwan dan Uhing, 2014; Rozzaid, Herlambang dan Devi, 2015; Potale dan Uhing, 2015.

The third hypothesis, "Internal motivation has a positive effect on job satisfaction of female workers." According Sutrisno (2011), motivation and job satisfaction have a strong relationship because every action that people do comes from the person's motivation. If the needs and goals of his life were achieved, then the person will be satisfied. This is consistent with what is happening at $\mathrm{X}$. The majority of employees work with the right motivation is responsible and have a sense of pride in the company. In other words, motivation has a significant effect on job satisfaction. This shows that internal motivation of female workers at $\mathrm{X}$ has a significant effect on job satisfaction. This result is supported by previous research by Kartika and Kaihatu, 2010; Ratnasari and Dewi, 2014; Mardiono and Supriyatin, 2014; Rozzaid, Herlambang and Devi, 2015.

There are some things that can be used as managerial implication to $\mathrm{X}$ for managing employee job satisfaction especially for female workers with focus to maintain supervisory, financial compensation, internal motivation as well:

1. For Supervisory, supervisor as managerial must continue to self-correct, also willing to accept criticism and suggestions from his subordinates. Two-way communication can help to be able knowing what things employees want from their superiors. There are various ways that employees can take in conveying their aspirations, including making critical letters and suggestions provided through the suggestion box or submitting criticisms and suggestions at routine work evaluation meetings.

2. For financial compensation, $X$ company must maintain the ongoing compensation system within the company, even improved to be even better if possible for the achievement of job satisfaction from the employees. In addition, companies should also pay attention to the rights of employees who may not be fulfilled at this time. For example giving appreciation to the best employees, provide a raise or give a gift of vacation packages with family.

3. For internal motivation, this proves that female workers have good internal motivation and correct in work. Thus $\mathrm{X}$ company next task is to find out and dig deeper into how employees can feel appreciated and needed. It can be implemented by good relationship, 
open management. Where possible, supervisor can be mentors, motivators, friends, even a complain mechanism for unsatisfied employees.

\section{Conclusion}

Here are the conclusions in this study: Supervisory has positive effects on job satisfaction of female workers. Then financial compensation has positive effects on job satisfaction of female workers. Also, internal motivation has positive effects on job satisfaction of female workers. There are several limitations in this study, namely: variables of this study limited, while there are many other variables that can affect job satisfaction. Sample technique used in this research only use judgment sampling technique which use some certain criterion in determining respondents. The sample used only female workers of $\mathrm{X}$, so the results of this study do not reflect to other companies.

\section{References}

[1] Ardana, I.s K., Mujiati, N. W. dan Utama, I. W. M. 2012. Manajemen Sumber Daya Manusia. Edisi Pertama, Yogyakarta: Graha Ilmu.

[2] Aziri, B. 2011. Job Satisfaction: A Literature Review. Management Research \& Practice, Vol. 3 (4), 77-86.

[3] Dessler, G. 2014. Fundamentals of Human Resource Management. Third Edition, Essex: Pearson.

[4] Firmansyah, F. 2008. Pengaruh Lingkungan Kerja, Kompensasi, Kepemimpinan Terhadap Kepuasan Guru dan Karyawan di SMA Wachid Hasyim Surabaya. Jurnal Tadris, Vol. 3 (1), 93-105.

[5] French, R. et al. 2015. Organizational Behaviour. Third Editon, John Wiley \& Sons.

[6] Ghozali, I. dan Latan, H. 2015. Partial Least Squares: Konsep, Teknik dan Aplikasi Menggunakan Program SmartPLS 3.0 Untuk Penelitian Empiris. Edisi Kedua: Universitas Diponegoro.

[7] Kartika, E. W., Kaihatu, T. S. 2010. Analisis Pengaruh Motivasi Kerja Terhadap Kepuasan Kerja (Studi Kasus Karyawan Restoran Pakuwon Food Festival Surabaya). Jurnal Manajemen dan Kewirausahawan, Vol. 12(1), 100-112

[8] Mawei, A. C., Nelwan, O., Uhing, Y. 2014. Kepemimpinan, Penempatan Kerja, Kompensasi Pengaruhnya Terhadap Kepuasan Kerja pada PT Bank BNI (Persero), Tbk. KCU Manado. Jurnal EMBA, Vol. 2 (2), 944-954.

[9] Mardiono, D., Supriyatin. 2014. Pengaruh Motivasi dan Disiplin Kerja Terhadap Kepuasan Kerja Karyawan. Jurnal Ilmu \& Riset Manajemen, Vol. 3(3), 1-19.

[10] Mathis, R. L. dan Jackson, J. H. 2011. Human Resource Management. Thirteenth Edition, Mason: South Western Cengage Learning.

[11] Milkovich, G., Newman, J. dan Gerhart, B. 2014. Compensation. Eleventh Editon, New York: McGraw Hill Education.

[12] Moleong, L. J. 2016. Metodologi Penelitian Kualitatif. Bandung: PT Remaja Rosdakarya Offset.

[13] Muttaqien, F. 2014. Pengaruh Kepemimpinan dan Motivasi Terhadap Kepuasan Kerja Karyawan Outsourcing PT BRI (Persero), Tbk. Cabang Lumajang. Jurnal WIGA, Vol. 4 (1), 19-33.

[14] Paripurna, I. G. D. 2013. Pengaruh Kepemimpinan, Lingkungan Kerja dan Komunikasi Terhadap Kepuasan Kerja. Vol. 2 (5), 581-593. 
[15] Potale, R., Uhing, Y. 2015. Pengaruh Kompensasi dan Stres Kerja Terhadap Kepuasan Kerja Karyawan pada PT Bank Sulut Cabang Utama Manado. Jurnal EMBA. Vol. 3 (1), 63-73

[16] Ratnasari, N. P. I., Dewi, A. A. S. K. 2014. Pengaruh Motivasi, Lingkungan Kerja Fisik dan Kepemimpinan Terhadap Kepuasan Kerja Karyawan. Vol. 3(7), 1911-1926.

[17] Rozzaid,Y.,Herlambang, T., Devi, A. M. 2015. Pengaruh Kompensasi dan Motivasi Terhadap Kepuasan Kerja Karyawan (Studi Kasus pada PT Nusapro Telemedia Persada Cabang Banyuwangi). Jurnal Manajemen dan Bisnis Indonesia. Vol. 1 (2), 195-214.

[18] Sari, E. 2009. Pengaruh Kompensasi dan Iklim Organisasi Terhadap Kepuasan Kerja. Jurnal Ilmu Administrasi dan Organisasi. Vol. 16 (1), 18-24.

[19] Schermerhorn, J. R. 2013. Introduction to Management. Twelfth Edition, Singapore: John Wiley \&Sons.

[20] Sekaran, U., Bougie, R. (2013). Research Methods for Business: A Skill Building Approach. Sixth Edition, West Sussex: John Wiley \& Sons.

[21] Sharma, M. K. dan Jain, S. 2013. Leadership Management: Principles, Models and Theories. Global Journal of Management and Business Studies. Vol. 3 (3), 309318.

[22] Sutrisno, E. 2011. Manajemen Sumber Daya Manusia. Jakarta: Kencana Prenada Media Group. www.bps.go.id/publication/2017/11/30/0daa04d8d9e8e30e43a55d1a/keadaanangkatan-kerja-di-indonesia-agustus2017.html. Accessed: March, 10, 2017.

[23] http://blog.id.jobplanet.com/tingkat-kepuasan-karyawan-bank-bank-terbesar-diindonesia/Accessed: March 10, 2017. 